\title{
Cross-sectional study of frequency and factors associated with stethoscope cleaning among medical practitioners in Pakistan
}

\author{
O. Hyder
}

$$
\text { عمر حيدة مستعرضة حول تواتر تنظيف سماعة الطبيب والعوامل المرتبطة به لدى الأطباء الملمارسين في باكستان }
$$

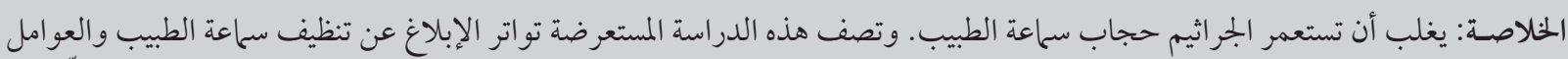

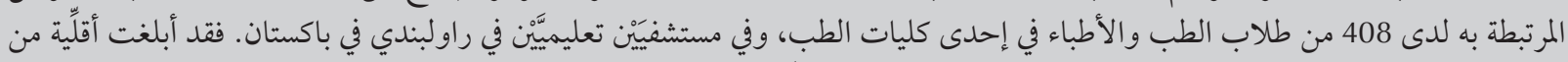

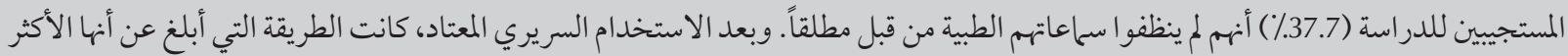

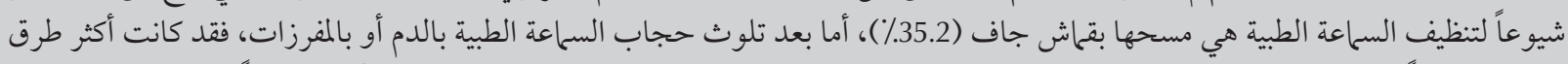

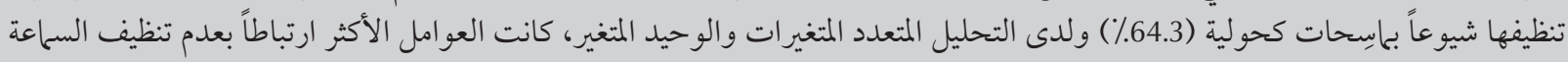

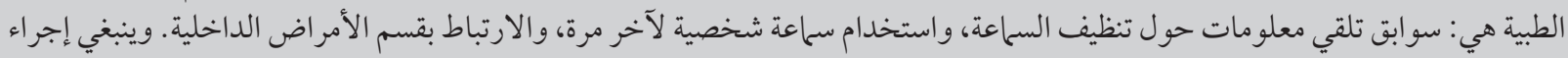

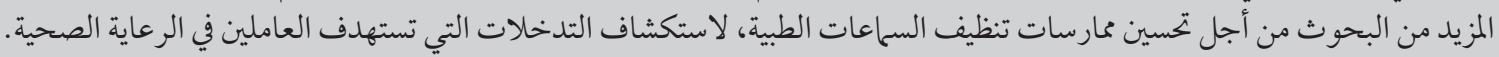

ABSTRACT Stethoscope diaphragms are frequently colonized by bacteria. This cross-sectional study described the frequency and factors associated with reporting ever cleaning stethoscopes among 408 medical students and doctors at a medical college and 2 teaching hospitals in Rawalpindi, Pakistan. A minority of the respondents $(37.7 \%)$ reported having ever cleaned their stethoscope. Following normal clinical use, wiping with a dry cloth was the most frequently reported method of cleaning (53.2\%). After contamination of the diaphragm with blood or secretions, cleaning with an alcoholic swab was the most common method (64.3\%). In univariate and multivariate analyses, history of receiving information on stethoscope cleaning, utilization of personal stethoscope at last use and affiliation with internal medicine department were factors strongly associated with ever cleaning of stethoscope. Future research for improving stethoscope cleaning practices should explore educational interventions aimed at health care professionals.

Étude transversale de la fréquence de nettoyage des stéthoscopes et des facteurs associés au nettoyage par les praticiens au Pakistan

RÉSUMÉ Le pavillon des stéthoscopes est fréquemment colonisé par des bactéries. La présente étude transversale décrit la fréquence de nettoyage des stéthoscopes et les facteurs qui y sont associés par 408 étudiants et médecins de la faculté de médecine et de deux centres hospitaliers universitaires de Rawalpindi (Pakistan). Une minorité de répondants $(37,7 \%)$ affirmaient avoir déjà nettoyé leur stéthoscope. Après une utilisation clinique classique, I'utilisation d'un chiffon sec était la méthode de nettoyage la plus fréquemment rapportée (53,2 \%). Après la contamination du pavillon par du sang ou des sécrétions, le nettoyage avec un tampon d'alcool était la méthode la plus répandue (64,3\%). Des analyses univariées et multivariées des résultats ont montré que le fait d'avoir reçu des informations sur le nettoyage du stéthoscope, l'utilisation d'un stéthoscope personnel lors de la dernière utilisation et l'affiliation à un service de médecine interne étaient des facteurs fortement associés à la pratique du nettoyage de l'instrument. Des recherches ultérieures devraient étudier la mise en ouvre d'interventions de formation destinées aux professionnels de santé afin d'améliorer les pratiques de nettoyage des stéthoscopes.

'Department of Obstetrics and Gynaecology, Rawalpindi Medical College, Rawalpindi, Pakistan (Correspondence to O. Hyder: hyder@post. harvard.edu).

Received: 09/01/11; accepted: 11/04/11 


\section{Introduction}

The stethoscope is a commonly used tool in clinical practice. Bacteria can be cultured from the diaphragms of the majority of stethoscopes in clinical use and can be as innocuous as normal skin flora or as potentially deadly as methicillin-resistant Staphylococcus aureus (MRSA) [1]. Regular cleaning of stethoscopes with alcohol-based disinfectants can reduce the presence of harmful bacteria on diaphragms, thus reducing the potential for nosocomial infection $[2,3]$. Studies from developed countries have shown that a majority of doctors do not clean or disinfect their stethoscopes on a regular basis [1-3].

Although developing countries have the highest burdens of communicable diseases, limited information is available on cleaning practices used by physicians for their stethoscopes. Africa-Purino et al. reported that none of the physicians or medical students working at the infectious ward at their university hospital in Manila, Philippines, reported daily or even weekly cleaning of their stethoscopes [4]. Lower pathogenic bacterial colony counts have been noted on samples cultured from the diaphragms of personal stethoscopes when compared with colony counts from communal stethoscopes [5]. It is not know whether receiving information on cleaning and disinfection affects doctors' cleaning preferences. No studies have specifically explored clinical factors associated with stethoscope cleaning practices either in developing or developed countries.

This aim of this cross-sectional study was to describes the frequency and factors associated with self-reported ever cleaning of stethoscopes among medical students and physicians at a medical college and two teaching hospitals in Rawalpindi, Pakistan.

\section{Methods}

\section{Setting and sample}

The study was carried out in May and June 2010. The hospitals, with a combined bed strength of 1350 , serve as primary care as well as specialist referral centres. Lists of the physicians working at the hospitals were obtained. All doctors on duty at the departments of general surgery, internal medicine, gynaecology and obstetrics, paediatrics, radiology and pathology were contacted in person, and given the pre-tested questionnaire which was collected 1 hour later. Investigators visited the hospitals during office hours for 3 consecutive days to contact physicians who had not been available on previous day(s). From a listed combined departmental strength of 344 , a total of 328 physicians (95.3\%) were provided with the questionnaire. Another group of 231 5thyear medical students of Rawalpindi Medical College who attended clinical clerkships at these hospitals, were given the questionnaire during a lecture, to be completed and collected after 1 hour. Fully complete questionnaires were returned by $73.2 \%$ (240/328) physicians and $72.7 \%(168 / 231)$ medical students, for a total of 408 respondents. Ethical approval for the study was granted by the research oversight authority of Rawalpindi Medical College and allied teaching hospitals.

\section{Data collection}

The variables recorded in the questionnaire were sex of the respondent, departmental affiliation or medical student, regular or irregular use of stethoscope, utilization of personal or communal (ward) stethoscope at the last use, history of ever receiving information or advice regarding cleaning or disinfection of their stethoscope and whether they had ever cleaned their stethoscope or not. Those reporting ever having cleaned their stethoscope(s) were asked about the frequency of cleaning and methods of cleaning following normal clinical usage and following contamination of the stethoscope with blood or bodily secretions from patients.

\section{Data analysis}

The data were managed and analysed using SPSS, version 16. The choice of factors for exploration of associations was based on previous studies reporting factors associated with positive bacterial culture results from doctors' stethoscopes [1-6]. Odds ratios (OR) and $95 \%$ confidence intervals (CI) for univariate analysis were calculated using logistic regression. $P<0.05$ was considered statistically significant. Significantly different variables were included as explanatory variables in the multivariate logistic regression model, with cleaning of stethoscope (ever/ never) as the response variable.

\section{Results}

Use of a stethoscope on a daily basis was reported by $59.8 \%$ respondents (244/408), while all others had used a stethoscope at least once during the last month. Regarding ownership of the stethoscope they used the last time, 89.0\% (363/408) utilized their personal stethoscope, while the rest had used a communal (ward) stethoscope. Only 17 respondents (4.2\%) had ever received information or advice regarding cleaning or disinfection of their stethoscope.

Only 154 respondents (37.7\%) reported having ever cleaned their stethoscope diaphragm. Among these respondents, regular cleaning was reported by 38 (24.7\%), while the rest did it on an irregular basis (Table 1). Among those who reported ever cleaning their stethoscope, the favoured method of cleaning following normal clinical use was with a dry cloth (53.2\%). After contamination with blood or body fluids 64.3\% used alcohol swabs (Table 2). 


\begin{tabular}{lrcc}
\hline $\begin{array}{l}\text { Table 1 Frequency of cleaning stethoscope diaphragm by physicians and medical } \\
\text { students }\end{array}$ & No. & $\begin{array}{c}\text { \% of ever cleaned } \\
(\boldsymbol{n}=\mathbf{1 5 4})\end{array}$ & $\begin{array}{c}\text { \% of total } \\
(\boldsymbol{n}=\mathbf{4 0 8})\end{array}$ \\
\hline Frequency of cleaning & 38 & 24.7 & 9.3 \\
Regular cleaning & 0 & 0.0 & 0.0 \\
After every patient & 19 & 12.3 & 4.7 \\
Daily & 10 & 6.5 & 2.5 \\
Weekly & 4 & 2.6 & 1.0 \\
Monthly & 5 & 3.2 & 1.2 \\
Yearly & 116 & 75.3 & 28.4 \\
Irregular cleaning & 30 & 19.5 & 7.4 \\
Weekly & 60 & 38.9 & 14.7 \\
Monthly & 14 & 9.1 & 3.4 \\
Yearly & 12 & 7.8 & 2.9 \\
Once every few years & 154 & 100.0 & 37.7 \\
Total (ever cleaned) & & &
\end{tabular}
cally significant associations between ever cleaning of stethoscope and receiving any information on cleaning of stethoscopes (OR $=4.21,95 \% \mathrm{CI}$ : 1.45-12.19), regular use of stethoscope ( $\mathrm{OR}=2.47,95 \% \mathrm{CI}: 1.60-3.79)$, personal stethoscope utilized at last use $(\mathrm{OR}=3.06,95 \% \mathrm{CI}: 1.44-6.51)$ and affiliation with the department of internal medicine $(\mathrm{OR}=3.50,95 \% \mathrm{CI}$ : 1.93-6.36). No association was noted between sex and reporting ever cleaning of stethoscopes. analysis, receiving information on cleaning $(\mathrm{OR}=3.34,95 \% \mathrm{CI}: 1.45-12.19)$, use of personal stethoscope at last utilization ( OR $=3.38,95 \%$ CI: 1.24 9.20), affiliation with medicine ( $\mathrm{OR}=$ $2.27,95 \%$ CI: $1.10-4.67)$, and affiliation
Univariate analysis found statisti-

On multivariate logistic regression

with radiology or pathology $(\mathrm{OR}=2.78$, 95\% CI 1.11-6.97) were independently associated with ever cleaning of stethoscope $($ all $P<0.05)($ Table 3$)$.

\section{Discussion}

This study found that less than $40 \%$ of doctors and medical students had ever cleaned their stethoscope diaphragm. Wiping with a dry cloth was the most frequently used method. Having received information about cleaning of stethoscopes showed the strongest association with reporting ever cleaning a stethoscope.

This was the first study specifically exploring factors associated with cleaning of stethoscopes in Pakistan. Moreover, it was also the largest study

\begin{tabular}{|c|c|c|c|c|}
\hline \multirow[t]{2}{*}{ Method of cleaning } & \multicolumn{2}{|c|}{ After normal clinical use } & \multicolumn{2}{|c|}{$\begin{array}{l}\text { If contaminated with } \\
\text { blood or body fluids }\end{array}$} \\
\hline & No. & $\%$ & No. & $\%$ \\
\hline Alcohol swab & 53 & 34.4 & 99 & 64.3 \\
\hline Soap and water & 6 & 3.9 & 18 & 11.7 \\
\hline Plain water & 8 & 5.2 & 15 & 9.7 \\
\hline Dry cloth & 82 & 53.2 & 18 & 11.7 \\
\hline Other method & 5 & 3.2 & 4 & 2.6 \\
\hline
\end{tabular}

on stethoscope cleaning from a developing country with a high burden of communicable diseases. The study was restricted to one medical college and two of its affiliated teaching hospitals, thus generalizability to all medical settings in developing countries would be limited. However, the findings regarding the reported frequency of cleaning of stethoscopes are similar to those noted from another developing country [4] and also from developed countries [1-3]. Although a previous study in the Philippines by Africa-Purino et al. reported a low frequency of regular cleaning [4], the present study used a larger sample size (408 versus only 30 ), covered multiple medical specialties and presented factors associated with ever cleaning of stethoscopes. The findings of the present study extend those from previous studies and are useful for establishing stethoscope cleaning guidelines in medical settings in developing countries.

It has been shown that after a day of not disinfecting a stethoscope in regular clinical use, contaminating bacteria can be cultured from the stethoscope diaphragm and the number of colony forming units increases daily $[3,7]$. It was noted that less than $5 \%$ of all respondents in the present study cleaned stethoscopes regularly on a daily basis. Although this frequency was higher than the study by Africa-Purino et al., in which none of the doctors or medical clerks reported cleaning stethoscopes on a regular daily or even weekly basis [4], it is still very low considering the risk of cross-infection posed by contaminated stethoscopes.

The use of cleaning agents among those who had ever cleaned their stethoscopes was disappointing. Following normal clinical use, the most popular method of cleaning was with a dry cloth. It is doubtful that wiping with a dry cloth would have a major effect on the level of contamination of the diaphragm. Ethyl alcohol has been shown to be a good disinfectant, while soap is also 


\begin{tabular}{|c|c|c|c|c|c|c|}
\hline \multirow[t]{2}{*}{ Characteristic } & Total & $\begin{array}{l}\text { Ever } \\
\text { cleaned }\end{array}$ & $P$-value ${ }^{a}$ & $\begin{array}{l}\text { Unadjusted } \\
\text { OR }(95 \% \mathrm{CI})\end{array}$ & $P$-value ${ }^{b}$ & $\begin{array}{l}\text { Adjusted } \\
\text { OR }(95 \% \mathrm{CI})^{c}\end{array}$ \\
\hline & No. & $\%$ & & & & \\
\hline \multicolumn{7}{|l|}{$\begin{array}{l}\text { Received information on } \\
\text { cleaning }\end{array}$} \\
\hline Yes & 17 & 70.6 & 0.008 & $4.21(1.45-12.19)$ & 0.033 & 3.34 (1.10-10.10) \\
\hline No & 391 & 36.3 & & Ref. & & Ref. \\
\hline \multicolumn{7}{|l|}{ Regular use of stethoscope } \\
\hline Yes & 244 & 45.9 & $<0.001$ & $2.47(1.60-3.79)$ & 0.105 & $1.56(0.91-2.68)$ \\
\hline No & 164 & 25.6 & & Ref. & & Ref. \\
\hline \multicolumn{7}{|l|}{ Last used stethoscope } \\
\hline Personal & 363 & 40.8 & 0.009 & $3.06(1.44-6.51)$ & 0.017 & $3.38(1.24-9.20)$ \\
\hline Communal & 45 & 13.3 & & Ref. & & Ref. \\
\hline \multicolumn{7}{|l|}{ Physician's sex } \\
\hline Male & 189 & 38.1 & 0.892 & $1.03(0.79-1.31)$ & - & - \\
\hline Female & 219 & 37.4 & & Ref. & & \\
\hline \multicolumn{7}{|l|}{ Department/affiliation } \\
\hline Medicine & 67 & 52.2 & $<0.001$ & $3.50(1.93-6.36)$ & 0.025 & $2.27(1.10-4.67)$ \\
\hline Surgery & 82 & 42.7 & 0.012 & $2.38(1.36-4.19)$ & 0.172 & $1.67(0.80-3.46)$ \\
\hline Paediatrics & 34 & 50.0 & 0.072 & $2.35(0.99-5.52)$ & 0.171 & $1.88(0.76-4.66)$ \\
\hline Obstetrics/gynaecology & 26 & 42.3 & 0.002 & $3.20(1.50-6.84)$ & 0.351 & $1.62(0.59-4.43)$ \\
\hline Radiology/pathology & 31 & 51.6 & 0.003 & $3.41(1.55-7.51)$ & 0.029 & $2.78(1.11-6.97)$ \\
\hline Medical student & 168 & 23.8 & & Ref. & & Ref. \\
\hline
\end{tabular}

${ }^{a} P$-value for univariate analysis; ${ }^{b} P$-value for multivariate analysis; ${ }^{~}$ After multivariable modelling adjusting for regular use. Ref. = reference category; $O R=$ odds ratio; $C I=$ confidence interval .

useful for disinfection [2,3]. Cleaning of diaphragms using ethyl alcohol swabs was more commonly reported after contamination with blood or bodily secretions (34.4\% after normal clinical use and $64.3 \%$ after contamination). In the absence of overt contamination, the less frequent use of an effective cleaning method may be due to a lower perceived risk of transmission of infection through the diaphragm in this situation.

The finding that having received previous information on stethoscope cleaning had a strong association with evercleaning ofstethoscopesfocuses attention on the role of educating medical professionals regarding cleaning of medical equipment. This finding is important for policy-makers aiming to initiate education programmes informing doctors about the risks posed by contaminated stethoscopes. It may also be noted here that due to the cross-sectional design of this study, reverse causation cannot be ruled out (i.e. perhaps the decision to clean the stethoscopes led doctors to access information regarding stethoscope disinfection and not vice versa). Longitudinal studies are warranted to determine the effect of education on stethoscope cleaning.

It has been previously noted that communally used stethoscopes can have a higher bacterial colony count than personal stethoscopes [5]. The present study noted that reporting the use of a personal stethoscope at the last utilization was strongly associated with reporting ever cleaning $(\mathrm{OR}=$ 3.38). Possible strategies to reduce the risk of cross-infection from communal stethoscopes could include reducing the use of communal stethoscopes by urging doctors to buy and use their own stethoscopes, and establishment of protocols for regular disinfection of communal stethoscopes by hospital staff.

A number of foci for future research have been identified by the present report. Cohort and interventional studies on the effect of educating health care professionals regarding disinfection of their stethoscopes, on bacterial colonization of diaphragms and nosocomial infection rates in the hospital are warranted. Differences in cleaning practices among doctors affiliated with various specialties of medical practice demand a review of the emphasis placed on disinfection of equipment in the prevailing practice guidelines of these specialties.

In summary, this study found that a minority of practising doctors and 
medical students in Pakistan cleaned their stethoscope diaphragms. Even those who cleaned stethoscopes tended to use an ineffective method of cleaning, i.e. wiping with a dry cloth. Having previous information about stethoscope cleaning, utilizing personal stethoscope at the last use and affiliation with the internal medicine department were notably associated with reporting ever cleaning of stethoscopes. There is need for further exploration of the role of educating health care providers about disinfection of medical equipment, in order to encourage regular and effective cleaning of stethoscopes used in clinical practice. This has the potential to reduce bacterial colonization of stethoscope diaphragms, and ultimately, nosocomial infection in hospitals settings.

\section{References}

1. Smith MA et al. Contaminated stethoscopes revisited. Archives of Internal Medicine, 1996, 156:82-84.

2. Núñez $\mathrm{S}$ et al. The stethoscope in the Emergency Department: a vector of infection? Epidemiology and Infection, 2000, 124:233-237.

3. Jones JS, Hoerle D, Riekse R. Stethoscopes: a potential vector of infection? Annals of Emergency Medicine, 1995, 26:296-299.

4. Africa-Purino FMC, Dy EER, Coronel RF. Stethoscopes: A potential source of nosocomial infections. Philippines Journal of Microbiology and Infectious Diseases, 2000, 29:9-13.
5. Bandi $\mathrm{S}$ et al. How clean are our stethoscopes and do we need to clean them? Journal of Infection, 2008, 57:355-356.

6. Mitchell A et al. Stethoscope or 'staphoscope'? Infection by auscultation. Journal of Hospital Infection, 2010, 76:278-279.

7. Genné D et al. Taux de contamination des stethoscopes en milieu hospitalier. [Level of stethoscope contamination in the hospital environment]. Schweizerische Medizinische Wochenschrift, 1996, 126:2237-2240.

\section{WHO Initiative on transformative scale-up of health professional education}

Scaling up educational programmes to produce multi-disciplinary service delivery teams - which include a carefully balanced mix of clinicians, community health workers and health managers - is urgent and essential. However, simply increasing the numbers of workers is not enough. The shortage of health workers is compounded by the fact that their skills, competencies, clinical experience, and expectations are often poorly suited to the health needs of the populations they serve.

The WHO Initiative on transformative scale-up of health professional education aims to support and advance the performance of country health systems so as to meet the needs of individuals and populations in an equitable and efficient manner. Driven by population health needs, transformative scale-up is a process of education system and health systems reform that addresses the quantity, quality and relevance of health care providers in order to increase access to health service and to improve population health outcomes.

Further information about the Initiative is available at: http://www.who.int/hrh/education/initiatives/en/index.html 